\title{
SELPI (Self-Exploring Learning Project Improvement) Practice in Terms of Student Learning Assessment
}

\author{
Ni’matul Istiqomah ${ }^{1 *}$, Prih Hardinto ${ }^{1}$, Nur Anita Yunikawati ${ }^{1}$, Magistyo Purboyo P. ${ }^{1}$ \\ ${ }^{1}$ Faculty of Economic, Universitas Negeri Malang, Malang, Indonesia \\ Corresponding author.Email: nimatul.istiqomah.fe@um.ac.id
}

\begin{abstract}
This study aims to determine the activeness and learning interest of students by using the SELPI teaching model, namely lecturers giving students the freedom to design their ways of learning through the preparation of Satuan Acara Perkuliahan (SAP) independently in study groups. This research is descriptive qualitative research. The data source is the learning assessment of students in the Economic Education Program. In this study, it will be known to learn classes with the SELPI model. The results of the study showed that students' activeness and interest in learning increased.
\end{abstract}

Keywords: SELPI, Learning Assessment, SAP, Self-Managed Learning

\section{INTRODUCTION}

Implementation in learning conducted by lecturers in class is one of the things that can increase learning output. Learning output is not only about high learning outcomes but also involves the activeness and interest in learning. A lecturer can measure output based on many criteria and ways. One of them is by applying learning methods. The selection of learning methods in this article refers to some of the results of field observations, namely

1) The freedom of students in making learning plans is very important to increase interest, activity and learning outcomes

2) The ability of students in economic education study programs in designing a learning design is one of the pedagogical abilities possessed by a prospective teacher.

3) By adjusting learning techniques and materials, it will produce an interesting learning model

4) In managing learning strategies in the classroom, a lecturer sees how the goals of higher education are in accordance with Undang-uandang No. 12 about higher education.

Higher Education aims:

a. the development of the potential of students to become human beings who have faith and be devoted to God Almighty and have good character, healthy, knowledgeable, capable, creative, independent, skilled, competent, and cultured for the benefit of the nation;

b. the production of graduates who master the branches of Science and/or Technology to meet national interests and increase national competitiveness;

c. the creation of Science and Technology through Research that pays attention to and applies the value of the Humanities to be beneficial to the progress of the nation, as well as the progress of civilization and the welfare of humanity; and

d. the realization of Community Service based on reasoning and research work that is useful in advancing public welfare and intellectual life of the nation.

Also, the goals of higher education are according to (Bourner, 1997).

a. Disseminate up-to-date knowledge.

b. Develop the capability to use ideas and information.

c. Develop the student's ability to test ideas and evidence.

d. Develop the student's ability to generate ideas and evidence.

e. Facilitate the personal development of students.

f. Develop the capacity of students to plan

g. and manage own learning.

Pada (Bourner, 1996) menyebutkan sebagai pendidik dia mendapatkan dua tujuan yaitu:

a. Disseminate up-to-date knowledge;

b. Disseminate ideas and information that would be useful to the students.

In Indonesia, based on Peraturan Pemerintah Republik Indonesia Nomor 60 Tahun 1999 about The Higher Education:

a. prepare students to become members of the community who have academic and/or professional abilities that can apply, develop and/or enrich the treasury of science, technology and/or art;

b. develop and disseminate science, technology and/or art and strive for its use to improve the lives of the people and enrich national culture.

The purpose of higher education in the Republic of Indonesia government regulation No. 60 of 199 concerning higher education is in accordance with the higher education goals stated by Bourner (1996, 1997). One that is very clearly seen is the self-development of 
students through knowledge and idea development in the study of their respective scientific fields. The second is the dissemination of knowledge, this is in accordance with the objectives of the bourner, namely developing the latest knowledge in certain scientific fields.

In individual learning can change towards better knowledge or increased knowledge. Individual learning activities always encourage thinking to be able to master a material concept. However, a project is sometimes not only done by individuals but in a group form. A person's ability to learn through group models is the ability to work in teams. Learning activities both through individual and team learning activities together encourage the desire to master a material concept. The level of learning a person does not stop at the level of the group alone but develops in a broader direction. As illustrated in the following chart according to Cunningham, I. (2017):

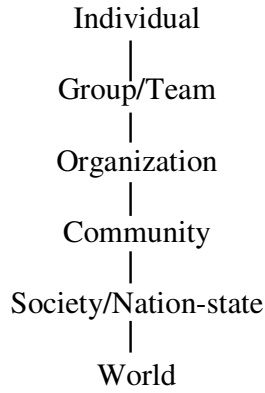

Figure 1.1 Levels of learning by Cunningman (2017)

Some studies mention that learning by independent learning can create its own experiences for students. As written by Ottewill (2002) in the UK, self-managed learning is of increasing significance since on many courses the waterline has been rising due to resource constraints. Besides, the management of independent learning also has several advantages, one of which is written by Abbott, J., \& Dahmus, S. (1992) that It enables learners to respond to the ever-changing information and skill requirements of the work environment and to match their needs with the learning content. In self-managed learning, each student can recognize their ability to learn. Students can develop their potential as well as others and the group Guy, R., Holden, F., \& Dickinson, P. (1994).

Based on the observations of researchers in the field, the problem that often occurs is the lack of interest and motivation that results in decreased learning outcomes both affective and cognitive. Cognitive learning outcomes in the form of numerical values from test results while affective learning outcomes in the form of activeness, critical thinking skills, and learning innovation. Development economics courses are compulsory courses taken by students of economic education courses. Development economics courses require deep learning not only learning in class but case studies are needed in the contextual understanding of the material.

With the variety of material in this development economics course, most students feel less motivated when studying if only based on textbooks or class presentations. They only accept without looking for case studies that are taking place considering the development economy is a subject that requires contextual deepening. Therefore, students need a learning model that suits their desires so that contextual learning is more easily understood by students.

The existence of these demands, we need a model that can increase student interest and motivation to learn. One model used to increase student interest and motivation is the SELPI method. The description of the design of this model is that students are free to study independently and design their own learning model in accordance with the material and interests of students.

\section{METHOD}

\subsection{Participants}

The population in this study were 4 classes which were taking semester 4 development economics courses. While the sample in this study was 1 class with a total of 35 students. Sampling using the purposive sampling method is described as a random selection of sampling units in a population segment with most information about interesting characteristics. (Guarte, J. M., \& Barrios, E. B. (2006)). The sample used in taking the sample is provided at the Lecture Program Unit which is compiled by highly creative students that are adapted to the economic development material applied in SELPI learning.

\subsection{Measuring Instrument}

This type of research is descriptive qualitative. Researchers used a questionnaire to determine student responses about the SELPI teaching model. The instrument used in this study was the Lecture Program Unit / Satuan Acara Perkuliahan (SAP) of each group to analyze the suitability and creativity of students in applying their learning methods with the material. In addition, given a pretest and posttest to measure students' understanding in understanding economic development material. In addition, other instruments used are in-depth interviews with students related to the learning methods used and student motivation.

\subsection{Procedure}

This research was conducted when students took semester 4 in the course of development economics. This research was conducted by direct observation of the implementation of SELPI learning methods in class.

\subsection{Data Analysis}

The analysis that will be achieved from this research is to determine student learning outcomes by applying SELPI learning methods. In addition, from in-depth interviews will be known student motivation. 


\section{RESULT AND DISCUSSION}

Based on this research it was found that the SELPI teaching model can increase the activity and interest in learning in the classroom. The SELPI teaching model has never been done before and this is new modeling. One of the highlights in this learning is that students design their own learning implementation along with the methods used in learning for the next semester. The output in this SELPI teaching model is SAP or Teaching Program Unit. Because the SELPI model is carried out in groups, this learning plan will bring up many creative ideas for implementing learning in one group.

Lecture Program Unit or SAP is a design made by lecturers at the beginning of lectures. Lecturers design materials and learning methods for 16 meetings or 1 semester. In this study, students design their own learning for one semester in accordance with student interests.

The steps used in SELPI are:

1. We got groups in the class (10 groups)

2. The lecturer gives the group time to design their own learning model

3. The lecturer gives students freedom in designing their learning in accordance with the material and interests of students

4. Students consult with lecturers

5. Students carry out RPS and SAP for the next semester

According to the researchers' observations, the SELPI model is very effective and motivates students to learn. According to the evaluation results from the lecturers, it was noted that students felt more active in learning, motivated to learn and students became more innovative in learning. Cognitive learning outcomes recorded by lecturers are very good and above the minimum completeness standard. In addition to cognitive learning outcomes, affective learning outcomes recorded by lecturers are students more responsible for their learning. Be more active during discussions. With the SELPI model, it is proven that it can increase student interest and active learning. Students are more creative in designing their way of learning and this will increase student interest and active learning. The results of research from several applications of learning methods say, learning with a contextual approach will help improve student learning outcomes (Istiqomah, N. M. (2011)).

\subsection{Student's $S A P$}

The output in this study is the SAP design or lecture event units arranged by students based on their interests and desires in learning. The design of learning by students is based on the material being explored and students' interest will learn in their own way. This SAP design is valid for one semester or 16 meetings arranged by groups from the class. This lecture unit consists of the achievement of courses, materials, activities in class, books or references used. In designing learning is not easy. Student consistency in designing their own learning model must be appropriate. Therefore, researchers chose students of economic education study programs at the 3rd level because the students were experienced in designing learning activities in a learning implementation plan (RPP).

\subsection{Learning Outcomes}

Learning outcomes in this study is effective learning outcomes or attitudes. Affective values seen are activeness and the ability to think critically. According to the questionnaire collected, students' interests and critical thinking skills were higher because students were freed to determine how to study according to their interests. In addition, students become more innovative in learning. Student interest can improve learning outcomes as quoted from the article Aritonang, K. T. (2008). Without interest and motivation, learning outcomes will be in accordance.

\subsubsection{Liveliness}

The increasing student learning activity can be seen from the observations of researchers at the time of learning. Students become more enthusiastic because they try to be responsible for the learning designs they make. Selfmanaged learning makes students more independent and motivated in conducting learning activities. In this development economics course, students not only study independently in the classroom but also make observations on field studies. Basically, we have experienced daily economic activities. Whether it's around state universities or in other environments. Based on this reason students design learning activities in field studies as an alternative case study.

\subsubsection{The Ability to Think Critically}

In addition to increasing learning activeness, students look to further enhance their critical thinking skills. This can be seen from field studies observing the state of the economy and analyzing their observations. This analysis is the focus of students' critical thinking skills. The results of the field study conducted by this student were presented in class together with classmates, not only listening to the results of the field study analysis from other friends, but they also criticized the results of the analysis

\subsubsection{Innovative}

Innovative is a person's ability to create new things. In this case, the innovative ability of students in designing their own learning is a result that deserves to be maintained in the learning system. The design of learning activities creates a 
new innovation that can make the learning atmosphere more effective.

\section{CONCLuSION}

Learning should take place fun and motivate students to learn. At present, the way of learning is more focused on the delivery of material and has not led to the independent learning process. One of the independent learning models for students is SELPI (Self-Exploring Learning Project Improvement). Learning by using the SELPI model in economic development subjects is very effective. This can be seen from the increase in student learning outcomes consisting of active learning, critical thinking skills, and innovative.

\section{REFERENCES}

[1] Indonesia, P. R. (2012). Undang-Undang Nomor 12 Tahun 2012 tentang Pendidikan Tinggi. Jakarta (ID): Sekretariat Negara.

[2] Bourner, T. (1997). Teaching methods for learning outcomes. Education+ Training, 39(9), 344-348. https://doi.org/10.1108/00400919710192377

[3] Bourner, T. (1996). The learning aims of higher education: A personal reflection. Education+ Training. https://doi.org/10.1108/00400919610117371

[4] Indonesia, P. R. (1999). Peraturan Pemerintah Republik Indonesia Nomor 60 Tahun 1999 tentang Pendidikan Tinggi. Sekretariat Negara Republik Indonesia. Jakarta.

[5] Cunningham, I. (2017). The wisdom of strategic learning: The self-managed learning solution. Routledge.

[6] Ottewill, R. (2002). Student self-managed learningcause for concern?. On the Horizon, 10(1), 12-16. https://doi.org/10.1108/10748120210431358

[7] bbott, J., \& Dahmus, S. (1992). Assessing the appropriateness of self-managed learning. Journal of Management Development, 11(1), 50-60. https://doi.org/10.1108/EUM0000000001390

[8] Guy, R., Holden, F., \& Dickinson, P. (1994). ICL learning about self-managed learning. Industrial and Commercial Training, 26(4), 8-10. Guy, R., Holden, F., \& Dickinson, P. (1994). ICL learning about selfmanaged learning. Industrial and Commercial Training, 26(4),

8-10.
[9] Guarte, J. M., \& Barrios, E. B. (2006). Estimation under purposive sampling. Communications in Statistics-Simulation and Computation, 35(2), 277-284. https://doi.org/10.1080/03610910600591610

[10] Istiqomah, N. M. (2011). Penerapan pembelajaran dengan menggunakan pendekatan contextual teaching and learning (CTL) melalui metode kooperatif teknik picture and picture untuk meningkatkan hasil belajar IPS ekonomi siswa kelas VIII SMP Negeri 12 Malang. Penerapan pembelajaran dengan menggunakan pendekatan contextual teaching and learning (CTL) melalui metode kooperatif teknik picture and picture untuk meningkatkan hasil belajar IPS ekonomi siswa kelas VIII SMP Negeri 12 Malang/Ni'matul Istiqomah.

[11] Aritonang, K. T. (2008). Minat dan motivasi dalam meningkatkan hasil belajar siswa. Jurnal pendidikan penabur, 7(10), 11-21. 